\title{
Pewadahan Etika Keilmuan di dalam UU Hak Cipta
}

\author{
Moh. Mahfud MD
}

\begin{abstract}
Abstrak
Some crucial problems related to scientific or academic ethics have been accomodated in Copy Rights Law which provides criminal sanctions against the breaker. However, the law could not reach or anticipate all kinds of academic ethic violations, because some of which had been very difficult to prove juridically.
\end{abstract}

\section{Pendahuluan}

Masalah pelanggaran atas etika keilmuan masih sering terjadi di dalam kegiatankegiatan ilmiah di Indonesia. Beberapa waktu yang lampau ada sebuah buku yang berbicara tentang plagiat-plagiat karya ilmiah yang mengambil contoh di sebuah perguruan tinggi ternama di Amerika Serikat yakni MIT.' Buku itu menyerang keras disertasi Yahya Muhaimin yang.kemudian diterbitkan oleh LP3ES dengan judul Bisnis dan Politik,
Kebijaksanaan Ekonomi Indonesia 1950$1980^{2}$ sebagai karya plagiat karena banyak kutipan-kutipan di dalamnya yang mengambil atau mengutip karya orang lain tanpa menyebut sumbernya secara jelas. Buku karya Ismet Fanany yang cenderung emosional ini memang sama sekali tidak membawa kesepakatan para akademisi bahwa karya Yahya adalah plagiat, sebab definisi plagiat itu sendiri belum jelas benar, apalagi disertasi Yahya itu

'Tepatnya buku tersebut ditulis oleh Ismet Fanany. 1992. Plagiat-plagiat di MIT, TragediAkademis di Indonesia. Jakarta:CV Haji Masagung. Jakarta.

2Lihat Yahya Muhaimin. 1991. Bisnis dan Politik, Kebijaksanaan Ekonomi Indonesia 1950-1980. Jakarta: LP3ES. 
telah menyebutkan semua bahan bacaannya di dalam daftar pustaka meskipun tidak mencantumkannya di dalam footnote atau bodynote. Selain itu sulit juga dikatakan bahwa karya Yahya itu plagiat karena yang dipersoalkan oleh Ismet Fanany bukanlah kesimpulan penelitian Yahya melainkan pendapat-pendapat yang hanya memberi bahan pada Yahya untuk kemudian membuat kesimpulan sendiri secara orisinal.

Tulisan ini tidak bermaksud membahas atau memberi academic appraisal atas masalah yang telah berlangsung cukup lama dan lebih bersifat politis itu, melainkan untuk menunjukkan bahwa di dalam kegiatan-kegitan keilmuan ada etika keilmuan yang harus diperhatikan oleh para ilmuan di dalam melahirkan karya-karya ilmiahnya. Seperti halnya dalam cipta karya seni, dalam cipta karya keilmuan pun seringkali terjadi "pencurian" gagasan yang kemudian diklaim sebagai karya sendiri. Tulisan ini, bermaksud mengurai kembali tentang etika keiimuan, serta apresiasi kaum terpelajar atasnya dan pengaturan hukum tentang masalah tersebut melalui UU tentang Hak Cipta.

\section{Etika keilmuan dan kebebasan akademis}

Dalam menulis karya ilmiah seseorang dituntut untuk banyak membaca karya-karya orang lain mengenai masalah-masalah yang relevan dengan apa yang akan ditulisnya. Tidaklah mungkin seseorang itu dapat membuat karya ilmiah secara baik kalau yang bersangkutan. tidak giat membaca hasil-hasil karya orang lain $^{3}$ baik dalam bentuk penelitian maupun publikasi-publikasi ilmiah populer maupun sekedar catatan sekilas tentang suatu masalah. Seperti diketahui bahan yang dapat digunakan untuk menulis karya ilmiah adalah informasi-infomasi ilmiah yang bisa didapatkan dengan pengalaman sendiri maupun yang ditulis sebagai berita atau karya ilmiah tersendiri. ${ }^{4}$

Dengan demikian karya ilmiah merupakan kristalisasi gagasan dari pikiran-pikiran si penulis setelah membaca berbagai informasi ilmiah tentang apa yang dipikirkannya dan telah ditulis oleh orang lain. ${ }^{5}$ Karya tulis ilmiah yang baik, dengan demikian, hanya dapat lahir dari pemanfaatan atas bantuan gagasan atau karya orang lain yang kemudian diolah sehingga menjadi buah pikiran ilmiah sendiri yang sifatnya baru. Namun hendaknya diingat bahwa dalam memanfaatkan karya orang lain ada etika keilmuan yang harus diperhatikan yakni keharusan penyebutan sumber secara jelas dalam setiap pemanfaatan karya orang lain. Suatu tulisan yang mengutip karya orang lain tanpa menyebut sumber secara jelas dan jujur merupakan pelanggaran atas etika keilmuan; mengambil sebagian kecil saja harus disebutkan sumbernya, apalagi jika pengambilan itu

${ }^{3}$ Moh. Mahfud MD. “Etika Keilmuan dan Dimensi Hukumnya, Rambu-rambu dalam Menggunakan Karya Orang Lain". makalah untuk Penataran Penulisan Karya Ilmiah untuk Dosen-dosen se-Kopertis Wilayah V. Yogyakarta. 16-21 Desember' 1996.

'Lihat dalam Winarno Surakhmat. 1978. Paper, Skripsi, Thesis, Disertasi. Bandung: Tarsito. Him. 2-5.

${ }_{5}^{5}$ Moh. Mahfud MD. Loc. Cit. 
sampai banyak atau mencapai seluruh isi sebuah tulisan. Selain melanggar etika keilmuan yang dapat dikualifikasi sebagai plagiat, pencurian gagasan seperti itu juga dapat dijatuhi hukuman pidana karena pelanggaran atas $U U$ tentang Hak Cipta sebagaimana diatur di dalam UU No. 12 Tahun 1997.

Masalah etika keilmuan ini ada kaitan erat dengan apa yang disebut sebagai kebebasan akademis, yakni kebebasan yang semula berkaitan dengan fungsi universitas atau perguruan tinggi untuk memenuhi kebutuhan masyarakat akan pendidikan tinggi. Untuk mendukung tujuannya dalam menyelenggarakan pendidikan tinggi yang berkualitas selain melakukan pendidikan dan pengajaran setiap universitas dapat melakukan penelitian-penelitian seperti halnya melakukan kegiatan pengabdian pada masyarakat. ${ }^{6}$ Jika sebuah perguruan tinggi hanya mengandalkan pendidikan dan pengajaran saja dan tidak mengimbanginya dengan kegiatan-kegiatan riset, maka perguruan tinggi tersebut tidak dapat dipandang sebagai perguruan tinggi dalam arti yang sebenarnya, sebab kegiatan penelitian merupakan wujud dari kegiatan ilmiah yang justru menjadi inti kegiatan perguruan tinggi. Parsudi Suparlan mengatakan bahwa universitas yang tidak melakukan kegiatan penelitian sebenarnya lebih tepat disebut sebagai lembaga kursus. Perguruan tinggi, terutama yang mengambil jalur akademik, tidak akan dapat melakukan fungsinya sebagai lembaga pengembang ilmu pengetahuan manakala tidak didukung oleh dosen-dosen yang selain mengajar juga melakukan penelitian dan kegiatan ilmiah lainnya. ${ }^{7} \mathrm{Di}$ dalam publikasinya yang bertajuk the Long View yang dimuat di dalam In Defense of Academic Freedom Sidney Hook mengatakan bahwa kebesaran sebuah universitas dapat terbangun karena hasil karya dosen-dosennya. ${ }^{8}$ Di sinilah terlihat betapa penting kebebasan akademik itu, sebab tanpa kebebasan akademik akan sulit bagi dosen untuk menghasilkan karya ilmiah yang bermutu dan obyektif; dan jika dosen tidak dapat bekerja di bawah perlindungan kebebasan akademis akan sulitlah bagi perguruan tinggi untuk menjadi besar karena karya dosen-dosennya. Dalam pandangan yang demikianlah maka birokrasi sebuah universitas pada hakikatnya merupakan kegiatan pengaturan dan pelayanan bagi terselenggaranya pendidikan tinggi, penelitian ilmiah, dan pengembangan ilmu pengetahuan yang mendorong, mengembangkan, dan memantapkan kebebasan ilmiah atau kebebasan akademis. Namun sering juga ditemukan bahwa kebebasan akademik diberi arti secara distortif sebagai kebebasan mengemukakan pendapat pada umumnya, termasuk kebebasan untuk melakukan demonstrasi atau unjuk rasa. Pemberian arti yang seperti itu salah, sebab kebebasan yang seperti itu adalah kebebasan biasa dalam arti politis yang juga dijamin sebagai hak setiap orang; hanya saja hal seperti itu tidak dapat disebut kebebasan akademis karena istilah ini mempunyai arti spesifik.

\footnotetext{
${ }^{6}$ Moh. Mahfud MD. "Perspektif Politik dan Hukum Tentang Kebebasan Akademik dan Kritik Sosial" dalam majalah UNISIA No.32/XVII/IV/1997.

'Edward Shils. 1993. Etika Akademis. Yayasan Obor Indonesia. HIm. xi-xii.

${ }^{8}$ Sidney Hook. 197. "The Long View" dalam In Defense of Academic Freedom. New York: Pegagus.
} 
Pada umumnya kebebasan akademik dikaitkan dengan dua wilayah perhatian yaitu: Pertama, kebebasan yang dimiliki oleh perguruan tinggi untuk melaksanakan fungsinya tanpa dicampuri oleh kekuasaan dari luar dirinya; kedua, kebebasan seseorang di dalam perguruan tinggi untuk belajar, mengajar, dan melaksanakan penelitian serta mengemukakan pendapatnya sehubungan dengan kegiatan tersebut tanpa ada pembatasan kecuali dari dirinya sendiri. ${ }^{9}$ Dari cakupan pengertian . tersebut, maka setiap warga elvitas akademika perguruan tinggi memiliki kebebasan akademik untuk mengoperasionalkan fungsi institusinya atau untuk kegiatan-kegiatan keilmuan dengan syarat dan prosedur tertentu.

Persyaratan tentang prosedur tertentu inilah yang antara lain, terkait dengan etika keilmuan dalam memanfaatkan karya-karya orang lain. Artinya meskipun memanfaatkan karya orang lain itu diperbolehkan dengan cara bebas namun ada etika yang berupa keharusan untuk menyebutkan sumber pengambilan atau pemanfaatan betapa pun orang yang diambil karyanya itu lebih rendah status atau reputasi akademiknya.

Dengan demikian selain tidak dapat diberi arti sembarangan kebebasan akademik itu dalam pelaksanaannya di bidang pemanfaatan karya orang lain haruslah dikerjakan di dalam bingḳai etika keilmuan atau etika akademis yakni pedoman moral yang tersirat di dalam kebebasan itu. Para dosen di perguruan tinggi atau para peneliti dan penulis misalnya harus memiliki pedoman moral dalam kegiatan profesinya yang biasa disebut etika. ${ }^{10}$ American Association of University Professors pernah memberikan rumusan yang cukup memadai tentang etika akademis melalui Statement of Proffesional Ethics yang dikeluarkan pada tahun 1966. Parsudi Suparlan di dałam Edward Shills" yang diambil dari Williams mengutip pernyataan tersebut bahwa yang dikatakan nilai-nilai etik yang terjalin dan terserap di dalam kebebasan akademis mencerminkan adanya hakikat kebebasan akademis sebagai kualitas kebebasan yang konsisten dengan disiplin atau bidang kesarjanaan dan nilai-nilai etika tersebut terjalin di dalam disiplin-disiplin kesarjanaan di dalam kegiatan belajar mengajar yang memuat hal-hal sebagai berikut: ${ }^{12}$

1. Profesor dibimbing oleh keyakinan yang mendalam mengenai nilai dan kehormatan kemajuan pengetahuan, mengakui adanya tanggungjawab yang khusus diletakkan di pundaknya. Tanggungjawab utamanya terhadap ilmu pengetahuan adalah mencari untuk menemukan kebenaran sebagaimana dilihatnya untuk kemudian menyatakannya. Untuk tujuan tersebut ia mengabdikan energinya untuk mengembangkan dan memper-

\footnotetext{
${ }^{9}$ Achmad Icksan. 1985. Mahasiswa dan Kebebasan Akademik. Malang-Yogyakarta: YP2LPM-Hanindita. Hilm. 53.

${ }^{10}$ Soelaeman Soemardi. "Etika dan Profesi, Pengantar ke Permasalahan". dalam Jurnal Sosiologi MASYARAKAT. No. 1.

"Edward Shils. Loc. Cit.

${ }^{12 M o h . ~ M a h f u d ~ M D . ~ " P e r s p e k t i f . . . . " ~ L o c . ~ C i t . ~}$
} 
baiki kompetisi kesarjanaannya. la menerima kewajiban untuk menggunakan disiplin diridan keputusan yang kritis dalam penggunaan, pengembangan dan pentransmissian pengetahuan. la mempraktikkan kejujuran intelektual."Walaupun ia boleh tertarik dan mengikuti sejumlah perhatian lainnya, tetapi perhatian-perhatian lainnya tersebut tidak boleh menghambat atau mengkompromikan kebebasan untuk menemukan dan menyatakan kebenaran.

2. Sebagai guru, professor memberisemangat dan mendorong muridmuridnya untuk belajar dengan semangat kebebasan. la harus mampu menujukkan di hadapan mereka patokan-patokan kesarjanaan yang terbaik yang ada dalam disiplin ilmu pengetahuannya. la harus mampu menunjukkan rasa hormatnya kepada muridnya sebagai individual, dan berpegang kepada peranannya sebagai pembimbing dan konselor intelektual. la harus melakukan berbagai usaha untuk membuahkan kejujuran akademik dan memastikan bahwa penilaianpenilaian yang ia berikan untuk kanyakarya murid-muridnya itu betu-betul sesuai dengan nilai yang seharusnya. la menghargai hakikat kerahasiaan pribadi dalam hubungan antara profesor dengan murid. la menghindari segala bentuk eksploitasi terhadap murid-muridnya yang menguntungkannya secara pribadi dan mengakui bantuan-bantuan mereka yang signifikan. la melindungi kebebasan akademis mereka.
3. Sebagai kolega, profesor mempunyai kewajiban-kewajiban yang berasal dari keanggotaan bersama dalam komunitas para sarjana. la menghormati dan melindungi kebebasan akademis para koleganya. Didalam tukarmenukar kritik dan ide-ide ia menunjukkan rasa hormat terhadap pendapat-pendapat lainnya. la mengakui hutanghutang budi akademis yang dimilikinya terhadap sarjana lain dan berjuang untuk tetap obyektif dalam penilaianpenilaian yang diberikan terhadap kolega-koleganya. la menerima bagian dari kewajiban-kewajiban sebagai dosen untuk terwujudnya ketertiban pranatanya atau universitasnya.

Tampak jelas dari pernyataan itu bahwa kejujuran untuk mengemukakan kebenaran ilmiah haruslah diutamakan termasuk di dalamnya memberikan penghargaan atau kredit bagi orang lain, bahkan pada para mahasiswanya, yang telah membantu dalam proses penemuan ilmiah itu. Dengan demikian penyebutan sumber pengambilan atas karya ilmiah orang lain menjadi sangat penting dan menjadi ukuran integritas ilmuwan yang bersangkutan. Jika penyebutan sumber itu diabaikan yang dapat menghilangkan jejak sumber aslinya sama sekali maka karya itu bisa menjadi karya plagiat. Dan jika hal itu terjadi maka integritas yang bersangkutan sebagai ilmuwan menjadi luntur.

\section{Pewadahan Hukum}

Pelanggaran atas etika akademis atau etika keilmuan pada umumnya masih belum terwadahi oleh hukum, artinya pelanggaran tersebut tidak dengan sendirinya dapat dituntut 
secara hukum kecuali dalam cara dan kualitas tertentu. Ini bisa dipahami karena hubungan antara etika dan hukum itu adalah hubungan gradual, artinya sebuah etika yang belum disahkan oleh pembuat UU sebagai hukum yang mengikat, maka pelanggaran atasnya tidak dapat dijatuhi sanksi yang sifatnya otonom (dipaksakan oleh kekuatan di luar si pelanggar). Seperti diketahui di dalam kehidupan bermasyarakat ada berbagai pedoman tingkah laku yang belum menjadi hukum dalam apa yang sering disebut dengan norma atau kaidah seperti norma kesusilaan, norma kesopanan, dan norma agama. Norma-norma tersebut tidak dapat dipaksakan dengan ancaman sanksi sebelum diterima sebagai hukum oleh lembaga pembuat hukum (legislatif), sehingga sanksi atas pelanggarannya lebih bersifat heteronom atau datang dari diri dan hatinya sendiri dalam bentuk penyesalan, rasa malu, rasa berdosa, dan sebagainya. ${ }^{13}$

Sebagian besar pedoman-pedoman tingkah laku di dalam etika keilmuan baru berupa norma (kesopanan) yang belum ditetapkan sebagai norma hukum. Namun dalam kualitas dan cara tertentu pencurian gagasan yang bersumber dari pelanggaran atas etika keilmuan itu telah juga diatur dengan hukum dan diancam dengan hukuman pidana berdasarkan ketentuan UU tentang Hak Cipta.

Perlindungan atas hak cipta merupakan salah satu bentuk perlindungan hukum yang diberikan oleh hukum atas kekayaan intelektual yang seluruhnya meliputi paten, merek, dan hak cipta dalam apa yang disebut Intelectual Property Rights. Intelektual Property Rights itu sendiri mencakup Industrial Property Rights (paten dan merek) dan Copy Rights (hak cipta). ${ }^{14}$ Perlindungan atas hak-hak tersebut berasal dari aturan hukum negara lain yang kemudian perkembangan masyarakatnya menuntut adanya hukum yang melindungi hak-hak atas kekayaan intelektual tersebut sampai ke negara lain. Indonesia sendiri mengikatkan diri dan terikat secara internasional setelah terjadi Putaran Uruguay yang berlangsung di Punta del Este tahun 1986. ${ }^{15}$

Jika ditelusuri secara historik sebenamya pelembagaan secara hukum mengenai perlindungan hak atas kekayaan intelektual belum begitu lama dikenal terutama atas apa yang dibahas dalam tulisan ini yakni mengenai hak cipta (copy rights). Di masa lalu perindungan hukum hanya diberikan atas hak-hak untuk lichamelijke zaak (benda-benda yang berwujud) sedang untuk onlimachelijke zaak (benda-benda yang tak berwujud) baru dikenal setelah abad XVIII.

Hak-hak atas tanah atau bangunan-bangunan yang ada di atasnya misalnya, sejak dulu telah mendapat perlindungan hukum sedangkan hak atas kekayaan intelektual baru dikenal dan diwadahi oleh hukum sejak kirakira dua abad yang lalu. Pada awal abad XVIII

${ }^{13}$ Lihat Wirjono Prodjodikoro. 1983. Azas-azas Hukum Tata Negara Indonesia. Dian Rakyat. Cet. V. HIm. 2; Juga Moh. Mahfud MD. 1993. Dasar dan Struktur Ketatanegaraan Indonesia. Yogyakarta: UII Press. HIm. 2-3.

${ }^{14}$ Moh. Mahfud MD. 1997. Aspek Hukum dalam Ekonomi dan Bisnis. bahan kuliah di STIE Widya Wiwaha. Yogyakarta.

${ }^{15}$ Muladi. "Pidato Pengarahan Menteri Kehakiman RI". Pada acara Rapat Koordinasi Nasional Riset dan Teknologi XVII. tanggal 10-12Agustus 1999. 
apa yang sekarang dikenal sebagai hak cipta atau copy rights belumlah diakui sebagai hak tersendiri sehingga jika ada orang yang menciptakan satu karya untuk orang lain, misalnya hadiah untuk seseorang yang dihormati, maka produk yang telah diberikan dan hak atas karya itu menjadi milik si penerima hadiah. Si penerima hadiah itulah yang kemudian mempunyai hak untuk mempublikasikan atau membuat copy bahkan juga melakukan perubahanperubahan atas hadiah yang telah diterimanya meskipun itu bukan ciptaannya sendiri. Di masa lalu ada kebiasaan bahwa penyebutan nama pencipta atau komponis karya seni tidak diperlukan jika misalnya sang komponis membuat karya atas pesanan seseorang yang membayarnya; setelah ciptaan diserahkan dan yang bersangkutan membayar honorarium sesuai dengan jumlah yang disepakati, maka saat itu pula hak untuk mempublikasikan dan memperbanyaknya menjadi milik si pemesan. ${ }^{16}$ Namun, tuntutan perlindungan hukum kemudian berkembang ketika sejak abad XVI ditemukan percetakan yang dapat memperbanyak berbagai naskah karya ilmiah, sastra, dan musik yang dapat dipergunakan untuk mencari keuntungan melalui kegiatan dagang ke seluruh dunia. Dirasakan menjadi tidak adil lagi jika karya atau ciptaan yang diperbanyak memperoleh untung yang besar sementara penciptanya sendiri tidak mendapat bagian, apalagi setelah terjadi kompetisi antarperusahaan percetakan dan penerbitan dalam berbagai disain yang menimbulkan kecenderungan untuk saling mematikan. Dalam keadaan inilah kemudian timbul ide tentang perlunya perlindungan hukum bagi penerbit agar tidak dirugikan. Yang pertamatama digagas dalam upaya pemberian perlindungan itu justru tidak kepada pencipta (author) melainkan ditujukan untuk penerbit dan pencetak agar investasinya dalam membiayai penerbitan dan pencetakan dilindungi. Rasa ketidakadilan kemudian muncul manakala perlindungan itu hanya diberikan kepada pencetak dan penerbit, sedangkan penciptanya diabaikan. Maka pada abad XVIII di Inggris menguat gagasan bahwa hak cipta atau perlindungan hukum atas ciptaan justru harus diberikan kepada pencipta, bukan kepada yang memperbanyak ciptaan. Penciptaan yang harus diperlakukan sebagai orang yang memiliki hak alamiah (natural right) sebagai hak atas ciptaannya sendiri termasuk hak untuk menjual hak itu kepada penerbit atau produser dalam waktu tertentu. Penerbit atau produser itu hanya mempunyai hak untuk menerbitkan, memperbanyak, dan memperdagangkannya selama masih dalam kurun waktu yang diberikan secara sah berdasarkan perjanjian dengan penciptanya. Setelah masa pemberian hak itu habis, maka si pencipta dapat memperpanjang perjanjiannya dengan penerbit atau produser semula dan dapat juga menjualnya kepada produser lain yang dianggapnya lebih cocok sebagai produser atas karya-karyanya.

${ }^{16}$ Lihat Sudargo Gautama. 1995. Segi-segi Hukum Hak Milik Intelektual. Bandung: Eresco. HIm. 3-4. juga dalam Moh. Mahfud MD. Aspek....Loc. Cit. 
Perkembangan itu terkait juga dengan kejadian di Perancis yang pada tahun 1777 memberikan hak tertentu kepada pencipta, sehingga hak pengutamaan yang sebelumnya dimiliki oleh penerbit dihilangkan. Perkembangan yang merupakan bagian dari gelora Revolusi Perancis ini kemudian dituangkan di dalam Undang-Unidang tahun 1791 dan 1793. Apa yang berkembang di Inggris dan Perancis ini kemudian diikuti oleh berbagai negara, sehingga pada abad XIX pengakuan atas hak cipta ini mendapat tempat secara internasional sesuai dengan hasil Konvensi Bern tahun 1886. Sejak itulah kemudian hak kekayaan intelektual atas ciptaan menjelma menjadi hak khusus yang dimiliki oleh pencipta atau pengarang untuk melakukan eksploitasi maupun untuk mendapatkan fasilitas-fasilitas lain yang berkaitan dengan karya ciptaannya itu. ${ }^{17} \mathrm{Pe}-$ lembagaan secara hukum tentang perlindungan ini diperlukan agar tidak terjadi peniruan dan pembajakan secara tidak jujur atas kreativitas intelektual dalam bidang ilmu pengetahuan, teknologi, dan seni sehingga keuntungan ekonomis dan moril yang timbul darinya tidak hanya dinikmati orang yang tidak turut menciptakannya. ${ }^{18}$

\section{Akomodasi Yuridis di Indonesia}

Seperti telah dikemukakan di atas, perlindungan hukum hak atas kekayaan intelektual di Indonesia ini terwadahi di dalam hukum for- mal setelah ada desakan dari negara-negara lain agar Indonesia melindungi Hak Atas Kekayaan Intelektual (HAKI) yang dimiliki warga negara lain, yang ternyata, tidak jarang dibajak oleh warga negara Indonesia. Kasus pembajakan lagu Bob Geldof-atau buku-buku karangan orang asing dapat disebut sebagai contoh yang dianggap merugikan penciptanya, yang juga mendorong gencarnya desakan agar Indonesia mewadahi dengan hukum yang tegas atas $\mathrm{HAKI}$ yang dimiliki oleh setiap orang, meskipun orang tersebut bukan warga negara indonesia. ${ }^{19}$ Hasil perundingan tentang perdagangan intemasional yang terkait dengan General Agreement on Tarrifs and Trade (GATT) memperkuat dorongan itu, apalagi beberapa negara maju semakin mengandalkan kegiatan ekonomi dan pada dagangannya pada produk-produk yang dihasilkan atas dasar kemampuan intelektual manusia seperti penelitian-penelitian yang menghasilkan penemuan dalam bidang teknologi. ${ }^{20}$ Dengan adanya GATT yang merupakan kerangka dasar penjanjian perdagangan multinasional dan menciptakan iklim perdagangan bebas, perlakuan yang sama serta pertumbuhan ekonomi yang berasaskan liberalisasi, maka keharusan bagi adanya hukum yang memberi jaminan atas HAKI menjadi kenyataan yang tidak dapat dihindari. Diawali dengan Uruguay Round tahun 1986 yang kemudian disusul dengan pertemuan internasional di Marakesh, Maroko pada bulan

"7Paul Goldstein. 1997. Hak Cipta : Dahulu, Kini, dan Esok. Jakarta: Yayasan Obor Indonesia. Hlm. 3-4. ${ }^{18}$ Moh. Mahfud MD. 1999. "Perlindungan Hukum untuk Cipta Seni”. Belum dipublikasikan. Disiapkan untuk jurnal SEN/ yang diterbitkan oleh Institut Seni Indonesia. Yogyakarta.

${ }^{19} / \mathrm{bid}$.

${ }^{20}$ Muladi. Loc. Cit. 
April tahun 1994 berbagai negara menghasilkan kesepakatan tentang hasil perundingan yang paling lengkap yang pernah dihasilkan oleh GATT yakni Convention Establishing the World Trade Organization yang di dalamnya tercakup pula Agreement on Trade Related Aspects of intelectual Property Rights (TRIPS) atau Aspek-aspek Perdagangan Hak atas Kekayaan Intelektual. Di dalam TRIPs ini dimuat norma-norma dan standar perlindungan bagi karya intelektual manusia dan serta pengaturan tentang pelaksanaan penegakan hukum di bidang HAKI tersebut. Negara Indonesia sendiri kemudian meratifikasi Convention Establishing the World Trade Organization itu dengan UU No. 7 Tahun 1994; sedangkan UU yang secara khusus terkait dengan HAKI yang telah dimiliki oleh Indonesia adalah UU No. 12 Tahun 1997 tentang Perubahan atas UU No. 6 Tahun 1982 sebagaimana telah diubah dengan UU No. 7 Tahun 1987 tentang Hak Cipta, UU No. 13 Tahun 1997 tentang Perubahan atas UU No. 6 Tahun 1989 tentang Paten, dan UU No. 14 Tahun 1997 tentang Perubahan atas UU No. 19 Tahun 1992 tentang Merek sebagai Pengganti UU No. 21 Tahun 1961 tentang Merek Perusahaan dan Merek Perniagaan. ${ }^{21}$

\section{Akomodasi Etika Keilmuan dalam UU}

\section{Cakupan}

Seperti dikemukakan di atas, artikel ini bermaksud menelaah pewadahan hukum atas hak cipta terutama hak cipta yang berkaitan dengan karya tulis ilmiah dan pelaksanaan etika akademis atau etika keilmuan. Dengan adanya UU tentang Hak Cipta (terakhir UU No. 12 Tahun 1997), maka sebenarnya setiap karya ilmiah telah dilindungi oleh hukum Indonesia dari kemungkinan pencurian gagasan secara total (menyeluruh) dengan perkecualian tertentu, tetapi hukum di Indonesia tidak mengakomodasi atas kemungkinan terjadinya pelanggaran atas etika akademis atau etika keilmuan secara menyeluruh, sebab hanya sebagian saja dari pelanggaran atas etika itu yang dapat dikenakan tindakan hukum. Namun, sebelum masalah ini diuraikan lebih lanjut, ada baiknya dikemukakan dulu beberapa pengertian dan pengaturan pokok tentang hak cipta sebagaimana diatur di dalam undang-undang. Di dalam Pasal 1 UU No. 12 Tahun. 1997 telah diatur secara stipulatif tentang masalah-masalah yang berkaitan dengan hak cipta yang antara lain menyebutkan:22

(1) Pencipta adalah seseorang atau beberapa orang secara bersama-sama yang atas inspirasinya lahir satu ciptaan berdasarkan pikiran, imajinasi, kecekatan, keterampilan atau keahlian yang dituangkan dalam bentuk yang khas dan bersifat pribadi.

(2) Ciptaan adalah hasil setiap karya pencipta dalam bentuk yang khas dan menunjukkan keasliannya dalam lapangan ilmu pengetahuan, seni, dan sastra.

\section{$21 /$ bid}

22Dikutip secara utuh dari Pasal 1 ayat (1), (2), (3), (4) UU No. 12 Tahun 1997. 
(3) Pemegang Hak Cipta adalah Pencipta sebagai pemilik hak cipta atau orang yang menerima hak tersebut dari Pencipta atau orang lain yang menerima lebih lanjut hak dari orang tersebut di atas.

(4) Pengumuman adalah pembacaan, penyuaraan, penyiaran atau penyebaran sesuatu ciptaan, dengan menggunakan alat apa pun dan dengan cara sedemikian rupa sehingga suatu ciptaan dapat dibaca, didengar, atau dilihat oleh orang lain.

Pada bagian lain ditegaskan pengertian bahwa hak cipta adalah hak khusus bagi pencipta maupun penerima hak untuk mengumumkan atau memperbanyak ciptaannya maupun memberi izin untuk itu dengan tidak mengurangi pembatasan-pembatasan menurut peraturan perundang-undangan yang berlaku. ${ }^{23}$ Jika sebuah pertanyaan diajukan tentang siapakah yang dianggap sebagai pencipta atas satu ciptaan, maka Pasal 5 menentukan bahwa yang dianggap sebagai pencipta adalah orang yang namanya terdaftar dalam Daftar Umum Ciptaan dan Pengumunan Resmi tentang Pendaftaran pada Departemen Kehakiman, kecuali terbukti sebaliknya. Yang dimaksud dengan terbukti sebaliknya adalah adanya bukti kuat yang dapat digunakan untuk membatalkan hak cipta yang telah dinyatakan sebagai milik orang lain di dalam Daftar Umum Ciptaan yang dibuat oleh Departemen Ke- hakiman. Sedangkan jenis-jenis ciptaan yang dilindungi sebagai ciptaan ditentukan di dalam Pasal 11 yang cakupannya meliputi ciptaan dalam bidang ilmu pengetahuan, seni, dan sastra, yaitu:

1. Buku, program komputer, pamflet, susunan perwajahan karya tulis yang diterbitkan, dan semua hasil karya tulis lainnya.

2. Ceramah, kuliah, pidato, dan ciptaan lainnya yang diwujudkan dengan cara diucapkan.

3. Alat peraga yang dibuat untuk kepentingan ilmu pengetahuan.

4. Ciptaan lagu atau musik dengan atau tanpa teks, termasuk karawitan, dan rekaman suara.

5. Drama, tari (koreografi), pewayangan, pantomim.

6. Karya pertunjukan.

7. Karya siaran.

8. Seninupa dalam segala bentuk seperti lukisan, gambar, seni ukir, seni kaligrafi, seni pahat, seni patung, kolase, seni terapan yang berupa seni kerajinan tangan.

9. Arsitektur.

10. Peta.

11. Seni batik.

12. Fotografi.

13. Sinematografi.

14. Terjemahan, tafsir, saduran, bunga rampai, dan karya lainnya dari hasil pengalihwujudan.

\footnotetext{
${ }^{23}$ Lihat dalam Pasal 2 ayat (1) UU No. 12 Tahun 1997.
} 


\section{Perkecualian}

Tampak jelas bahwa UU tentang Hak Cipta telah mengatur secara konkret tentang jenis ciptaan yang dilindungi dari pelanggaran atau pemanfaatan hak secara tidak sah oleh orang lain. Namun, ada beberapa jenis produk ciptaan yang bisa dimanfaatkan tanpa harus meminta izin dulu pada pihak lain karena dianggap oleh hukum sebagai milik publik; artinya jenis-jenis produk ciptaan tertentu dapat diperbanyak dan diumumkan tanpa harus meminta persetujuan lebih dulu. Hal ini diatur di dalam Pasal 13 yang menyebutkan bahwa "bukan merupakan pelanggaran" jika seseorang mengumumkan atau memperbanyak sesuatu yang diumumkan oleh atau atas nama pemerintah, kecuali apabila hak cipta itu dinyatakan dilindungi baik dengan peraturan perundang-undangan maupun dengan pernyataan pada ciptaan itu sendiri atau ketika ciptaan itu diumumkan. Juga dinyatakan bukan pelanggaran jika seseorang mengambil, baik seluruhnya atau sebagian, berita dari kantor berita, badan atau penyiar radio atau televisi dan surat kabar setelah $1 \times 24$ jam terhitung dari saat pengumuman pertama - berita itu dan sumbernya harus disebutkan secara lengkap.

Selanjutnya di dalam Pasal 14 disebutkan juga bahwa asalkan sumbernya disebutkan atau dicantumkan maka, hal-hal di bawah ini, tidak dianggap sebagai pelanggaran hak cipta:

a. Penggunaan ciptaan pihak lain untuk keperluan pendidikan, penelitian, penulisan ilmiah, penyusunan laporan, penulisan kritik dan tinjauan suatu masalah dengan ketentuan tidak merugikan kepentingan yang wajar bagi pencipta. b. Pengambilan ciptaan pihak lain baik seluruhnya maupun sebagian guna keperluan pembelaan di dalam dan luar pengadilan.

c. Pengambilan ciptaan pihak lain baik seluruhnya maupun sebagian guna keperluan:

1. ceramah yang semata-mata untuk tujuan pendidikan dan ilmu pengetahuan.

2. Pertunjukan atau pementasan yang tidak dipungut bayaran dengan ketentuan tidak merugikan kepentingan yang wajar bagi pencipta.

d. Perbanyakan suatu ciptaan bidang ilmu pengetahuan, seni dan sastera dalam huruf braille guna keperluan para tuna netra, kecuali jika perbanyakan itu bersifat komersial.

e. Perbanyakan suatu ciptaan selain program komputer, secara terbatas dengan cara-cara atau alat apa pun atau proses yang serupa oleh perpustakaan umum, lembaga ilmu pengetahuan atau pendidikan dan pusat dokumentasi yang non komersial, semata-mata untuk keperluan aktivitasnya.

f. Perubahan yang dilakukan atas karya arsitektur seperti ciptaan bangunan berdasarkan pertimbangan pelaksanaan teknis.

g. Pembuatan salinan cadangan sesuatu program komputer oleh pemilik program komputer yang dilakukan semata-mata untuk kepentingan sendiri.

UU Hak Cipta juga memberikan perhatian yang positif bagi pengembangan ilmu pengetahuan, ternyata dari ketentuan Pasal 15 yang menyatakan bahwa untuk kepentingan pendidikan, ilmu pengetahuan, dan kegiatan 
penelitian dan pengembangan, sesuatu ciptaan yang dilindungi hak cipta dan selama tiga tahun sejak diumumkan belum diterjemahkan ke dalam bahasa Indonesia, pemerintah setelah mendengar pertimbangan Dewan Hak Cipta, dapat mewajibkan pemegang hak cipta untuk melaksanakan sendiri penerjemahan dan/atau perbanyakan ciptaan tersebut di wilayah Indonesia dalam waktu yang ditentukan. Untuk keperluan ini pula pemerintah dapat mewajibkan pemegang hak cipta yang bersangkutan untuk memberikan izin kepada orang lain untuk menerjemahkan dan/atau memperbanyak ciptaan tersebut di wilayah negara Republik Indonesia dalam waktu yang ditentukan, dalam hal pemegang hak cipta yang bersangkutan tidak melaksanakan sendiriatau menyatakan ketidaksediaan untuk melaksanakan kewajiban sebagaimana menerjemahkan atau memperbanyak ciptaannya itu. Dan dalam hal pemegang hak cipta tidak melaksanakan kewajiban untuk menerjemahkan atau memperbanyak sendiri atau memberi izin kepada orang lain, untuk itu, maka pemerintah dapat melaksanakan sendiri penerjemahan dan/ atau perbanyakan ciptaan tersebut.

\section{Celah-celah Pelanggaran Etika}

Uraian di atas menunjukkan bahwa beberapa hal pokok yang dituntut di dalam etika akademis atau etika keilmuan telah diakomodasikan di dalam UU, terutama da- lam masalah pengambilan karya orang lain. Bahkan UU Hak Cipta di Indonesia dalam memberikan perlindungan atas hak cipta itu bukan saja membuka peluang bagi yang punya hak untuk menggunakan hukum perdata, tetapi juga mengatur dari aspek pidana. Di dalam Pasal 44 UU Hak Cipta disebutkan ancaman pidana yang tidak ringan bagi siapa pun yang melanggar hak cipta orang lain dengan pengaturan sebagai berikut :24

Pertama, diancam dengan pidana penjara paling lama tujuh tahun dan/atau denda paling banyak Rp. 100.000 .000 ,- (seratus juta rupiah) bagi siapa pun yang tanpa hak mengumumkan atau memperbanyak suatu ciptaan atau memberi izin untuk itu.

Kedua, diancam dengan pidana penjara paling lama lima tahun dan/atau denda paling banyak Rp. 50.000.000,-(lima puluh juta rupiah) bagi siapa pun yang dengan sengaja menyiarkan, memamerkan, mengedarkan, atau menjual kepada umum suatu ciptaan atau barang hasil pelanggaran seperti yang disebut pada butir pertama.

Ketiga, diancam dengan pidana penjara paling lama tiga tahun dan/atau denda paling banyak Rp. 25.000.000,- (dua puluh lima juta. rupiah) bagi siapa pun yang mengumumkan setiap ciptaan yang dilarang oleh pemerintah untuk diumumkan karena bertentangan dengan kebijaksanaan pemerintah di bidang pertahanan dan keamanan negara, kesusilaan, serta ketertiban umum. ${ }^{25}$

${ }^{24}$ Dikutip dari Pasal 44 UU No. 12 Tahun 1997 khusus yang terkait dengan ilmu pengetahuan.

${ }^{25}$ Kewenangan pemerintah untuk ini diatur di dalam Pasal 16 UU No. 12 Tahun 1997 yang berbunyi "Pemenintah setelah mendengarkan pertimbangan Dewan Hak Cipta dapat melarang pengumuman setiap ciptaan yang bertentangan dengan kebijaksanaan Pemerintah di bidang pertahanan dan keamanan negara, kesusilaan, serta ketertiban umum." 
Meskipun akomodasi hukum terhadap etika keilmuan sudah jelas di dalam UU Hak Cipta yang disertai pula dengan ancaman pidana yang tidak ringan, namun tidak semua pelanggaran atas etika keilmuan dapat diselesaikan secara hukum; artinya masih ada celah yang dapat dimasuki oleh seseorang untuk melanggar etika akademis atau etika keilmuan tanpa harus khawatir dijerat dengan hukuman. Yang dapat diakomodasi oleh hukum pada umumnya adalah yang diambil secara utuh terutama susunan redaksionalnya. Tentang etika menyebut sumber pengambilan pendapat dari seseorang misalnya, bisa saja seseorang melakukan pelanggaran secara etis tetapi tidak melanggar secara yuridis. Terutama di dalam ilmu-ilmu sosial, seseorang bisa mengambil pendapat orang lain dan menyajikan dengan kalimatnya sendiri tanpa menyebut sumbernya secara jelas, baik di dalam catatan kaki atau catatan perut (footnote atau bodynote) maupun di dalam daftar pustakanya. Yang kelihatan tidak melanggar tetapi sebenarnya masih melanggar etika keilmuan adalah mengambil pendapat orang dari sebuah tuilisan, tetapi sumbernya hanya disebut secara umum di dalam daftar pustaka, bukan di dalam footnote atau bodynote, sehingga sulit dikenali bagian mana dari tulisan itu yang diambil dari setiap sumber yang ada di dalam daftar pustaka. Tidak jarang juga seseorang tidak mentaati etika akademis yang dengan cara seenaknya dan tanpa beban tidak memberikan kredit sama sekali kepada orang-orang yang telah turut memberikan bahan bagi karyanya. Bahkan ditengarai tidak sedikit dosen perguruan tinggi yang mengambil data penelitian bekas mahasiswanya untuk dikemas dengan judul dan analisis baru tanpa memberi kredit kepada mahasiswanya. Banyak juga di antara para penulis yang kaget ketika pendapat yang pernah ditulisnya muncul di sebuah buku karangan orang lain tetapi tidak disebut sumbernya. Jika pendapat itu telah disadur dalam bahasa si "pencuri gagasañ" akan sulit dilakukan penuntutan hukum sebab bisa saja si "pencuri" mengaku bahwa tulisan itu adalah pendapatnya sendiri yang orisinal. Ini adalah kasus pelanggaran atas etika akademis.

Jadi sebenamya di dalam pergaulan ilmiah masih banyak sekali terjadi pelanggaran atas etika akademis, tetapi sulit dijaring dengan tuntutan yuridis berdasarkan UU Hak Cipta, terutama di dalam ilmu-ilmu sosial, karena formulasi hukum tentang ini lebih tertuju pada penggunaan karya orang lain yang diambil dengan kalimat utuh.

\section{Simpulan}

Di dalam upaya membangun atau memajukan ilmu pengetahuan dan teknologi yang sangat dibutuhkan oleh ummat manusia, terdapat aturan-aturan tingkah laku yang harus ditaati yakni etika akademis atau etika keilmuan. Yang pokok dalam etika akademis ini adalah kejujuran ilmiah yang menuntut setiap penggiat keilmuan untuk menyebut sumber pengambilan pendapat seseorang atau data bahan karya secara jelas.

Sebagian dari masalah-masalah yang dicakup di dalam etika keilmuan atau etika akademis ini telah diakomodasikan atau diwadahi di dalam UU tentang Hak Cipta yang disertai dengan ancaman hukuman pidana yang tidak ringan bagi yang melanggarnya. Namun, akomodasi hukum tentang hak cipta ini tidak dapat menjangkau atau mengantisipasi seluruh kemungkinan pelanggaran atas etika akademis, karena ada pelanggaran 
"etis" yang sulit dibuktikan secara "yuridis" karena sifat pelanggarannya yang memang dikaburkan. Dan ini masih kerapkali terjadi di dalam tata pergaulan ilmiah, seperti yang dikemukakan di atas.

Oleh sebab itu, pendidikan untuk membangun kesadaran dan penghayatan atas etika keilmuan atau etika akademis harus tetap digalakkan di berbagai lembaga pendidikan bahkan juga di tengah-tengah masyarakat, sebab banyak jenis pelanggaran akademis yang dapat dijangkau oleh UU Hak Cipta. $\square$

\section{Daftar Pustaka}

Babbie, E.R. 1973. Survey Research Methods. Belmont: Wardsworth Publishing Company.

Badrulzaman, Miriam. 1994. Aneka Hukum Bisnis. Bandung: Alumni.

Brush, Stephen G. "Theory and Facts in Science". Dalam DIALOGUE Vol. 10. №. 2.

Fanany, Ismet. 1992. Plagiat-plagiat di MIT, Tragedi Akademis di indonesia. Jakarta: CV Hajil Masagung.

Gautama, Sudargo. 1995. Segi-segi Hukum Hak Milik Intelektual. Bandung: Eresco, cet. li.

Goldstein, Paul. 1997. Hak Cipta: Dahulu, Kini, dan Esok. Jakarta: Yayasan Obor Indonesia.

Himawan, Charles et.al. 1972. Business Law. Lembaga Penelitian Hukum dan Kriminologi. Fakultas Hukum Unpad. Bandung.

Hofstader, R. dan WP Metzger. 1955. The Development of Academic Freedom in the United State. Columbia. New York.
Hook, Sidney. 1971. "The Long View" dalam in Defense of Academic Freedom. New York: Pegagus.

Icksan, Ahmad. 1985. Mahasiswa dan Kebebasan Akademik. MalangYogyakarta: YP2LPM-Hanindita.

Jatim, Fatimah dan Dewi Djarot. "Segi-segi Hukum Pemberian Lisensi Paten". Makalah untuk seminar di Fak. Hukum UI. Jakarta. 28 Pebruari 1997.

MD, Moh. Mahfud "Etika Keilmuan dan Dimensi Hukumnya". Makalah untuk Penataran Penulisan Karya IImiah Dosen di Kopertis Wilayah V. tanggal 16 s/d 21 Desember 1996.

_-1997. Aspek Hukum dalam Ekonomi dan Bisnis. Bahan kuliah untuk STIE Widya Wiwaha. Yogyakarta.

- "Perspektif Politik dan Hukum tentang Kebebasan Akademik dan Kritik Sosial". Dalam majalah UNISIA No. 32/XVIIIIVI 1997.

"Perlindungan Hukum untuk Cipta Seni". Belum dipublikasikan. Disiapkan untuk jurnal SEN/ yang diterbitkan oleh Institut Seni Indonesia. Yogyakarta.

Muladi. "Pengarahan Menteri Kehakiman Rl" pada Rapat Koordinasi Nasional Riset dan Teknologi, di Jakarta tanggal 1012 Agustus 1999.

Project, Elips. 1993. Secured Transaction.

Purwosutjipto, HMN. 1991. Bentuk-bentuk

Perusahaan - 2. Jakarta: Djambatan.

Shils, Edward. 1993. Etika Akademis. Jakarta:

Yayasan Obor Indonesia. 
Sjahputra, Iman dan Arif Djohan Tunggal (penghimpun). 1997. Peraturan Perundang-undangan Hak Cipta, Paten dan Merek, Jakarta: Harvarindo.

Subekti, R. 1977. Aneka Perjanjian. Bandung: Alumni.

Surachmad, Winarno. 1971. Paper, Skripsi, Thesis, Disertasi. Bandung: CV Tarsito.
_. 1978. Dasar dan Teknik Research. Bandung: CV Tarsito.

Soelaeman, Soemardi. "Etika dan Profesi, Pengantar ke Permasalahan," dalam Jurnal Sosiologi MASYARAKAT. No. 1.

Undang Undang No. 12 Tahun 1997 tentang Perubahan atas UU No. 6 Tahun 1982 tentang Hak Cipta. Sebagaimana telah diubah dengan UU No. 7 Tahun 1987. 